\title{
THE EFFECT OF SERVICESCAPE ON REVISIT INTENTION IN RESTAURANTS: THE ME- DIATING EFFECT OF BRAND FAMILIARITY ${ }^{1}$
}

\author{
Seray Gulertekin Genc ${ }^{\mathrm{a}}$, Volkan Genc, \\ ${ }^{\mathrm{a}}$ Batman University, School of Tourism and Hotel Management, Batman, Turkey. \\ ORCID: 0000-0002-0655-2856 / e-mail: seray.gulertekingenc@batman.edu.tr \\ ${ }^{\mathrm{b}}$ Batman University, School of Tourism and Hotel Management, Batman, Turkey. \\ ORCID: 0000-0001-5887-0568 / e-mail:volkangnc@yahoo.com
}

\begin{tabular}{ll} 
KEYWORDS & ABSTRACT \\
\cline { 2 - 2 } $\begin{array}{l}\text { Servicescape } \\
\text { Brand familiarity }\end{array}$ Revisit intention & $\begin{array}{l}\text { The purpose of this study is to examine the multidimensional structure of servicescape (substantive and } \\
\text { communicative) in restaurants to understand the effect of brand familiarity on customer revisit intention. } \\
\text { Testalt Theory }\end{array}$ \\
$\begin{array}{l}\text { The data were collected from the branches of a restaurant in Istanbul. Quantitative research methods were } \\
\text { used in this study. Data were collected from } 672 \text { visitors using the convenience sampling technique. Data } \\
\text { were analyzed by Bootstrap technique using SPSS Process Macro. The findings show that both the substantive } \\
\text { and communicative servicescape does not affect the restaurant customers' brand familiarity; however, brand } \\
\text { familiarity has been found to have a mediating role in revisit intention. Also, substantive and communicative } \\
\text { servicescape affect the revisit intention. The study extends the Gestalt Theory as also major considerations. }\end{array}$
\end{tabular}

\section{Introduction}

In restaurants, customers prefer restaurants to gain experience rather than meet their eating needs. Restaurants have both physical and non-physical elements that can affect service experiences. In restaurants, customer satisfaction consists of a harmony that includes the food's quality, employee behavior and attitude, and the environment (Genc, 2018). In this industry, more research is needed to examine the effects of servicescape on customers' experiences. Thus, the servicescape can be used as a tool to facilitate customers' experience evaluations (Durna, Dedeoglu \& Balikcioglu, 2015).

Restaurants are businesses where consumers spend a lot of time. Therefore, customers are likely to be affected by the restaurant's service arrangement (Ellen \& Zhang, 2014; Genc \& Akoglan Kozak, 2020; Wang \& Mattila, 2015). However, although the concepts of servicescape and familiarity are important for restaurants (Park, Back, Bufquin \& Shapoval, 2019), there is still a gap in our knowledge of this relationship. Until today, studies such as restaurant type (Kim \& Moon, 2009), pleasure (Lin \& Mattila, 2010), emotional states (Ellen \& Zhang, 2014), image (Jang, Ro \& Kim, 2015), authenticity (Wang \& Mattila, 2015), service climate (Chang,

\footnotetext{
${ }^{1}$ This study is the expanded version of the paper "The Effect of Servicescape on Revisit Intention in Restaurants: The Moderating Effect of Brand Familiarity" presented at the "Global Conference on Business and Economics (GLOBE)" congress held in Istanbul in 2019.
}

2016), density (Hanks, Line \& Kim, 2017), quality of life (Meng \& Choi, 2017), restaurant attitude (Hanks \& Line, 2018), loyalty (Turker, Gokkaya \& Acar, 2019) in the servicescape field attract attention in restaurants. More research is still needed to examine the underlying mechanism of how different elements of the servicescape affect customer behavior. However, while physical servicescape and communicative servicescape research are becoming common, relatively few studies have simultaneously evaluated this phenomenon.

Gestalt theory (Kim \& Moon, 2009; Lin \& Mattila, 2010) provides a theoretical basis for the effects of servicescape. The theory implies that everyone perceives the whole and makes sense of it (Wertheimer, 1938). That is, when a customer enters a restaurant, the employee perceives the components such as food, heat, light, smell, table, and music as a whole rather than separately and interprets that restaurant as a whole (Genc, 2018). Different components of the servicescape can be used as important instruments to influence customer behavior.

As familiarity increases, so can customer expertise, which can significantly affect customers'

${ }^{\star}$ Corresponding Author.

Received 30.12.2020; Received in revised form 20.01.2021; Accepted 31.01.2021 This article is licensed under a Creative Commons Attribution 4.0 International License. e-ISSN: 2687 - 3737 / @ 2021 The Authors. Published by Anadolu University. http://dx.doi.org/10.48119/toleho.850803 
responses. This is mainly because familiarity leads to a more detailed cognitive structure that can affect customers' emotional responses (Mitchell \& Dacin, 1996). Brand familiarity has been determined to play a role in the behavioral intentions of customers in restaurants (Tam, 2008). Brand familiarity in hotels has been found to play a moderating role between servicescape and behavioral intention (Park et. al, 2019). There is limited research into the mediating effect of familiarity, with a comprehensive staging of servicescape in restaurants. In light of the gaps mentioned above, this study explores the mediating effect of the servicescape on customers' revisit intention. It also examines the two main dimensions of servicescape, namely the substantive and communicative direct impact of customers on the revisit intention. The findings expand the existing literature including the communicative dimension as well as the specific dimension of servicescape. Moreover, it sheds some more light on servicescape studies with the mediating effect of familiarity.

\section{Literature Review}

\subsection{Servicescape}

Kotler (1973) expressed the visual, auditory, touch, and smell elements that appealed to the senses as the atmosphere in service businesses and specified the consumer as motivating factors. This study by Kotler has been used in service businesses for many years. Baker (1987), argued that the physical environment affects the way customers evaluate services. Booms and Bitner (1981) first coined the term servicescape as the environment where the service is brought together for the customers and the buyer and seller interact with each other. Bitner (1992), classified servicescape into signs, symbols, and artifacts, ambient conditions, spatial order, and functionality. Ryu and Jang (2008) created a dining space scale (DINESCAPE) as physical evidence in restaurants, such as facility aesthetics, lighting, positioning, food-related equipment, staff, and ambience. Han and Ryu (2009), focused on decor and artwork, spatial order, and ambient conditions to examine physical environmental factors in a restaurant context. Over the years, tourism researchers have focused on the servicescape's physical creations, attributing various elements to the servicescape (Dedeoglu, Bilgihan, Ye, Buonincontri, and Okumus, 2018). As previous research suggests, only physical components of the environment are often used in broader or narrower contexts and are often related to important servicescape stages (SSoS).

Bagozzi (1975), suggested that most marketplace exchanges are mixed, including tangible and intangible entities where consumers meet social and psychological needs. Therefore, in addition to physical and social stimuli such as interaction with employees also affect customer experiences (Park et al., 2019). Despite the importance of physical evidence for restaurant customers, few studies have focused on the servicescape's social aspects (Park et al., 2019). Such components often referred to as "communicative staging", are seen as an important channel for service employees to communicate with customers (Gwinner, Gremler \& Bitner, 1998). Communicative staging includes not only the individual of an organization but also its cultural components (Dong \& Siu, 2013). Harris \& Ezeh (2008), emphasized that interactions with other people should be included in addition to physical characteristics when conducting experiments based on customer service. Pizam and Tasci (2019) introduced the "experiencscape" term, which was developed by including an organizational hospitality culture that includes stakeholders. However, despite the restaurant industry's social nature, the lack of empirical research on communicative staging remains a concern.

\subsection{Effects of Substantive Servicescape on Restaurant Customers' Revisit Intention}

Mehrabian and Russel (1974), observed that the physical stimuli of an environment can directly affect people's behavior. The effect of atmosphere or physical design and decor components on consumers has been studied by much marketting researchers (Bitner, 1992). Servicescape is of crucial importance to customers' value perceptions (Dedeoglu et al., 2018). Studies dealing with different servicescape dimensions, including the substantive and communicative staging of the servicescape.

Harris and Ezeh (2008) found that perceptions of substantive affect loyalty. Kim and Moon (2009) servicescape (substantive) have determined that the perceived service quality is affected. In another study, Lin and Mattila (2010) determined that restaurants' servicescape and service encounters affect pleasure and satisfaction. Ellen and Zhang (2014) found that customers' substantive perceptions in the restaurant influenced their emotional state (pleasure and arousal), and through these emotions, their behavioral intentions. Dedeoglu, Kucukergin and Balikcioglu (2015) found that the substantive perceptions of tourists visiting hotels positively and significantly affect value, image, and taste. Meng and Choi (2018)'s study results found that the servicescape affects the planned behavior model. In their studies, Turker et al. (2019) found that both the direct/indirect external servicescape and the physical environment had the highest scores that positively affect customer loyalty. Also, according to Gestalt theory, both substantive staging and communicative staging function as stimuli.

This is related to the customers' perception of the restaurant as a whole. Finally, the substantive perceptions of customers led to behavioral intentions. In this context, substantive components in restaurants can be expected to positively affect brand familiarity and revisit components. In the restaurant, sounds, smells, physical elements, lighting, and the atmosphere and decor, can create positive emotions in the customers and thus meet 
the customers' pleasurable needs. Therefore, the following hypotheses regarding these expected relationships have been developed.

$\mathrm{H}_{1}$ : The servicescape (SSoS) in restaurants positively affects brand familiarity.

$\mathrm{H}_{2}$ : The servicescape (SSoS) in restaurants positively affects the revisit intention.

\subsection{Effects of Communicative Servicescape on Restaurant Customers' Revisit Intention}

In many previous studies using only the physical environment, the SOR theory proposed by Mehrabian and Russell was used. Studies with different theories were tried to be explained with the introduction of communicative factors. Many studies have also been done on the communicative dimension. It is seen that these studies have gained importance in the last five years. This is because it is understood that the human factor is as important as other factors (Genc \& Akoglan Kozak, 2020). Gestalt theory is also an important theory that explains the communicative dimension of servicescape. Jang et al. (2015) show that communicative factors affect restaurant image and, therefore, behavioral intention. Durna et al (2015) found that servicescape components in hotels positively affect the overall image and that the overall image has the same effect on word of mouth (WOM) and revisits. Chang (2016), on the other hand, shows that employee behavior contributes to the servicescape and found that it significantly affects the customer's consumption experience. Hanks et al. (2017) determined that density (resident and human) affects the perceptions of potential customers about a restaurant. Meng and Choi (2017) found that servicescape dimensions are associated with customer feeling, satisfaction, subjective well-being, and quality of life.

Dedeoglu et al. (2018) determined that servicescape factors positively affect hedonic value perceptions, and hedonic value perceptions positively affect behavioral intention. Hanks \& Line (2018) found that social servicescape is a robust predictor of post-consumption behavioral intentions, including attitude, satisfaction and return intention, and word of mouth. Lin and Hanks (2019), on the other hand, understood the role of the servicescape in the consumption process and emphasized the importance of social aspects besides the physical environment. Lockwood and Pyun (2019) found that the servicescape significantly affects both emotional and behavioral responses in hotels. Contrary to the above studies, Taheri, Olya, Ali and Gannon (2020) did not find a significant difference between social servicescape and passengers' dissatisfaction in their two airports study.

Similarly, restaurant staff's humanitarian components, interacting with guests, dialogue, and communicating with customers can also affect guests' brand familiarity and revisit intention. In this context, the second hypothesis of the research;
$\mathrm{H}_{3}$ : The servicescape (CSoS) in restaurants positively affects brand familiarity.

$\mathrm{H}_{4}$ : The servicescape (CSoS) in restaurants positively affects the revisit intention.

\subsection{Mediating Effects of Familiarity}

Lin (2013) showed that the harmony between common brands mediates the relationship between brand familiarity and purchase intention. Wang \& Mattila (2015) show that servicescape dimensions in ethnic restaurants can trigger pre-purchase authenticity perceptions of ethnic restaurants. They found that perceived authenticity, together with their familiarity with ethnic restaurants, influenced their intention to become customers. Park et al. (2019) show that both substantive and communicative servicescape affects hotel customers' emotions, which has an effect on satisfaction and thus increases behavioral intentions. Brand familiarity moderates the relationship between a significant servicescape and impact. Therefore, the following hypotheses have been developed regarding these expected relationships:

\section{$\mathrm{H}_{5}$ : Brand familiarity in restaurants affects revisit intention.}

$\mathrm{H}_{6}$ : Familiarity has a mediating role in the effect of the servicescape (SSoS) in restaurants on the revisit intention.

$\mathrm{H}_{7}$ : Familiarity has a mediating role in the effect of the servicescape (CSoS) in restaurants on the revisit intention.

\section{Methodology}

\subsection{Research Instrument}

A questionnaire form was created based on a comprehensive literature review. In this context, the servicescape developed by Durna et al. (2015) included 12 items for SSoS and nine items for CSoS. Brand familiarity is adapted from Lin (2013)'s study and 3 items; the revisit intention scale was adapted from Meng and Choi (2018)'s study and contained 3 items. Responses were measured using a five-point categorical scale. The scale ranged from "strongly disagree $=1$ " to "strongly agree $=5$ ". Finally, in the last part of the questionnaire, questions about the participants' gender, age, marital status, monthly income, number of restaurant visits were asked.

\subsection{Data Collection}

This study's sample is customers having dinner in 17 branches of a restaurant business in Istanbul destination. Since the research was conducted on servicescape and brand familiarity, a chain business group serving the same design and concept was chosen. The questionnaire forms were prepared only in Turkish and were made to the local participant. The scales in the questionnaire were originally developed in English. It was then translated into Turkish using the back translation procedure. First, experts translated the questionnaire into Turkish. 
Second, experts with the same qualifications have translated the questionnaires into English. During the back translation into English, different words with the same meaning are used. Then, a pilot implementation of the data collection tool was carried out with 50 participants in a branch of the restaurant. Based on the pilot test feedback, adjustments, and revised versions became final.

The study was carried out using the drop-andcollect survey technique and distributed between 14:00 and 18:00 when the service was slightly less intense. The drop-and-collect method was used because it allowed data to be collected from a large, representative sample of participants. It was carried out with the management's permission for this time zone not to disrupt the business's workflow. A total of 1000 questionnaires were applied using the convenience sampling technique; however, only 704 surveys were collected. 32 of the 704 questionnaires were missing. In this context, our 672 samples were included in the analysis.

\subsection{Analysis Method}

The SPSS Process Macro 3.3, developed by Hayes (2018) was used to test the hypotheses. Process Macro provides an appropriate analytical method to examine the relationships between variables in multivariate structures. First, the missing values were examined in the study. As a result of the analysis, it was determined that the data were randomly distributed. The average value was assigned in a way that would not disturb the general structure of the variable (Cokluk, Sekercioglu \& Buyukozturk, 2012). Then, it was examined whether there are extreme values in the data. In calculating one-sided extreme values, it is recommended to exclude data other than \pm 3 of the $Z$ scores (Cokluk et al., 2012). The data other than the extreme values of $\mathrm{Z}$ scores \pm 3 were considered separately and excluded from the study sample. After removing the extreme values, the skewness and kurtosis values were checked for normal distribution. It is stated that when the value of skewness and kurtosis is between \pm 1.5 , the normal distribution assumption is satisfied (Tabachnick \& Fidell, 2013).

\section{Results}

\subsection{Demographics of Respondents}

Approximately $60 \%$ of the participants are men. 621 of the participants stated their age, and the age range of these participants ranges between 17-68. The average age of the participants is approximately 32 . The education level of the participants is seen as a mode class undergraduate (49\%). $25.3 \%$ of the participants have an income of 2500 and below; $10.9 \%$ of the $2501-3500 ; 17.3 \%$ of $3501-4500 ; 20.2$ percent stated it as $4501-5500$ and $21.9 \%$ as 5500 and above. $4.5 \%$ of the participants also did not indicate their income. Approximately $77 \%$ of the participants stated that they visited the restaurant for the first time.

\subsection{Measurement Model}

Confirmatory factor analysis (CFA) was conducted to test the validity of the scale. Factor loadings of particular items were below 0.70. were removed (one SSoS and two CSoS items). As a result, the CFA's fit index (shown in Table 1) was at an acceptable level $\left(\chi^{2} / \mathrm{df}=4.821\right.$, RMSEA $=0.075, \mathrm{CFI}=0.96$ (Meydan $\&$ Sesen, 2011). Because standard factor loadings of all items were between 0.70 and 0.94 , all $t$ values were at a significant level, and averaged variance extracted (AVE) values exceed the recommended 0.50 value.

According to discriminant validity, it was observed that the model fulfilled the criteria of discriminant validity for the dimensions of servicescape, along with the dimensions of RVI and BF (Fornell \& Larcker, 1981). When the Cronbach alpha values were examined, $\mathrm{SSoS}=0.952 ; \mathrm{CSoS}=0.940 ; \mathrm{BF}=0.747$ ve $\mathrm{RVI}=0.811$ was found.

Harman's Single-Factor Approach (Podsakoff \& Organ, 1986) was used to control for common method bias (CMB). CFA for the control of CMB while six-factor models compared single-factor models through chi-square tests. The chi-square tests also demonstrated that the four-factor model was superior to the single-factor model $\left(\Delta \chi^{2}=2951.493\right.$; $\Delta \mathrm{df}=249, \mathrm{p}<0.05)$. Therefore, CMV was unlikely to cause major concern in this study.

\subsection{Testing of Hypothesized Direct and Indirect} Effects

The SPSS Process Macro 3.3 program developed by Hayes (2018) was used to test the research hypotheses, and the 4th Model developed by Hayes (2018) was used. The independent variable, dependent variable, and mediator variable were used in this model, and hypotheses with both direct and mediating effects were tested.

The bootstrap technique was used to test whether $\mathrm{BF}$ had a mediating role in the RVI effect of SSoS and $\mathrm{CSoS}$ of customers. In the analyzes, the 5000 resampling option was preferred with the bootstrap technique. The regression analysis results are given in Figure 1 and Table 2.

It has been determined that SSoS does not significantly affect $B F$ (path a) $(\beta=0.0004, p>0.05)$. Accordingly, the $\mathrm{H}_{1}$ hypothesis could not be supported. It has been determined that SSoS has a positive and significant effect on RVI (c and $\mathrm{cl}$ ) $(\beta=0.6062, t=19.9822, p<0.05)$. Accordingly, the $\mathrm{H}_{2}$ hypothesis was supported. It was concluded that SSoS explained $37 \%$ of RVI ( $\mathrm{F}=390.15, \mathrm{R} 2$ $=0.3680$ ). It has been determined that $\mathrm{CSoS}$ does not have a statistically significant effect on BF (path a) $(\beta=0.0033, p>0.05)$. Accordingly, the $\mathrm{H}_{3}$ hypothesis could not be supported. It has been determined that CSoS has a positive and significant effect on RVI ( $c$ and cl) $(\beta=0.6365, t=21.0280, p<0.05)$. Accordingly, the $\mathrm{H}_{4}$ hypothesis was supported. It was concluded that CSoS explained 39\% of RVI ( $F=433.11, R 2=0.3926)$. A statistically positive and significant effect of $\mathrm{BF}$ on RVI (path b) was determined ( $\beta=0.2367, t=4.1144$, $\mathrm{p}<0.05)$. Hence, the $\mathrm{H}_{5}$ hypothesis was supported. It 


\begin{tabular}{|c|c|c|c|c|c|c|}
\hline & 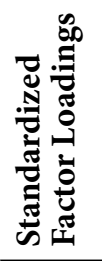 & 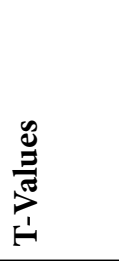 & 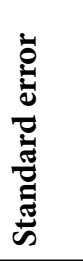 & $\approx$ & 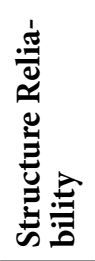 & 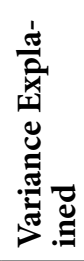 \\
\hline SSoS & & & & & 0.95 & 0.64 \\
\hline The background music in the hotel is pleasant & 0.771 & ${ }^{\star}$ Fixed & 0.41 & 0.59 & & \\
\hline The hotel has a nice smell & 0.797 & 22.856 & 0.36 & 0.64 & & \\
\hline The atmosphere of the hotel is cheerful & 0.743 & 20.872 & 0.45 & 0.55 & & \\
\hline The hotel is clean & 0.801 & 23.010 & 0.36 & 0.64 & & \\
\hline The hotel has up-to-date facilities & 0.789 & 22.508 & 0.38 & 0.62 & & \\
\hline The architecture of the hotel is attractive & 0.801 & 23.005 & 0.36 & 0.64 & & \\
\hline The signs used in the hotel are helpful to me & 0.878 & 25.974 & 0.23 & 0.77 & & \\
\hline The layout of their facilities makes it easy to use & 0.829 & 24.088 & 0.31 & 0.69 & & \\
\hline The color scheme of the hotel is attractive & 0.856 & 25.136 & 0.27 & 0.73 & & \\
\hline The decoration in the hotel is fashionable & 0.709 & 25.123 & 0.50 & 0.50 & & \\
\hline The facilities are maintained well & 0.784 & 21.893 & 0.39 & 0.61 & & \\
\hline CSoS & & & & & 0.94 & 0.69 \\
\hline The employees of the hotel are willing to help & 0.807 & ${ }^{\star}$ Fixed & 0.35 & 0.65 & & \\
\hline The employees of the hotel are polite and friendly & 0.821 & 32.885 & 0.33 & 0.67 & & \\
\hline The employees of the hotel give customers personal attention & 0.862 & 26.485 & 0.26 & 0.74 & & \\
\hline The employees of the hotel are passionate & 0.854 & 26.118 & 0.27 & 0.73 & & \\
\hline $\begin{array}{l}\text { The employees provided relief and comfort to me when I felt bored owing to } \\
\text { service waiting }\end{array}$ & 0.876 & 27.136 & 0.23 & 0.77 & & \\
\hline The employees are neat and gracefully dressed & 0.870 & 26.846 & 0.24 & 0.76 & & \\
\hline The symbols of the hotel are lovely & 0.704 & 20.070 & 0.50 & 0.50 & & \\
\hline BF & & & & & 0.78 & 0.55 \\
\hline I am familiar with the brand & 0.751 & ${ }^{\star}$ Fixed & 0.44 & 0.56 & & \\
\hline I recognize the brand & 0.762 & 12.792 & 0.42 & 0.58 & & \\
\hline I had heard of the brand before & 0.701 & 12.765 & 0.51 & 0.49 & & \\
\hline RVI & & & & & 0.86 & 0.67 \\
\hline I would like to revisit this restaurant in the near future & 0.785 & ${ }^{\star}$ Fixed & 0.38 & 0.62 & & \\
\hline If had to decide again. then I would choose this restaurant again & 0.936 & 16.058 & 0.12 & 0.88 & & \\
\hline I would more frequently visit this restaurant & 0.714 & 15.165 & 0.49 & 0.51 & & \\
\hline
\end{tabular}

SSoS=Substantive staging of hotel servicescape; $C S o S=$ Communicative staging of hotel servicescape; BF=Brand Familiar; RVI= Revisit Intention ${ }^{*}$ arameter fixed at 1.0 during ML estimation.

was concluded that $38 \%$ of RVI was explained by BF ( $F=208.18, R 2=0.3836) . H_{6}$ hypothesis is supported because the mediating effect of BF in SSoS's affecting RVI is not included in the confidence intervals of 0 (zero) ( $\beta$ : $0.020, \% 95$ CI $[-0.0096,0.0099]) . \mathrm{H}_{7}$ hypothesis is supported because the mediating effect of BF in CSoS's affecting RVI is not included in confidence intervals of 0 (zero) ( $\beta$ : $0.0180 \% 95 \mathrm{CI}$ $[-0.0089,0.0108])$.

\section{Discussion and Conclusions}

This study aims to examine the relationship between servicescape, brand familiarity, and revisit intention in restaurants. This study extends previous research by empirically testing the mediating role of brand familiarity in links between servicescape factors and revisit intention. The results show that servicescape factors influence revisit intention, and brand familiarity positively affects mediation. However, the effect of servicescape factors on brand familiarity could not be determined. Accordingly, theoretical and managerial implications are given below.

\subsection{Demographics of Respondents}

This study initially found that consistent with Park et al. (2019), the servicescape significantly impacts brand familiarity mediation and revisit intentions. This study adds to this line of research by revealing that SSoS and CSoS do not impact brand 


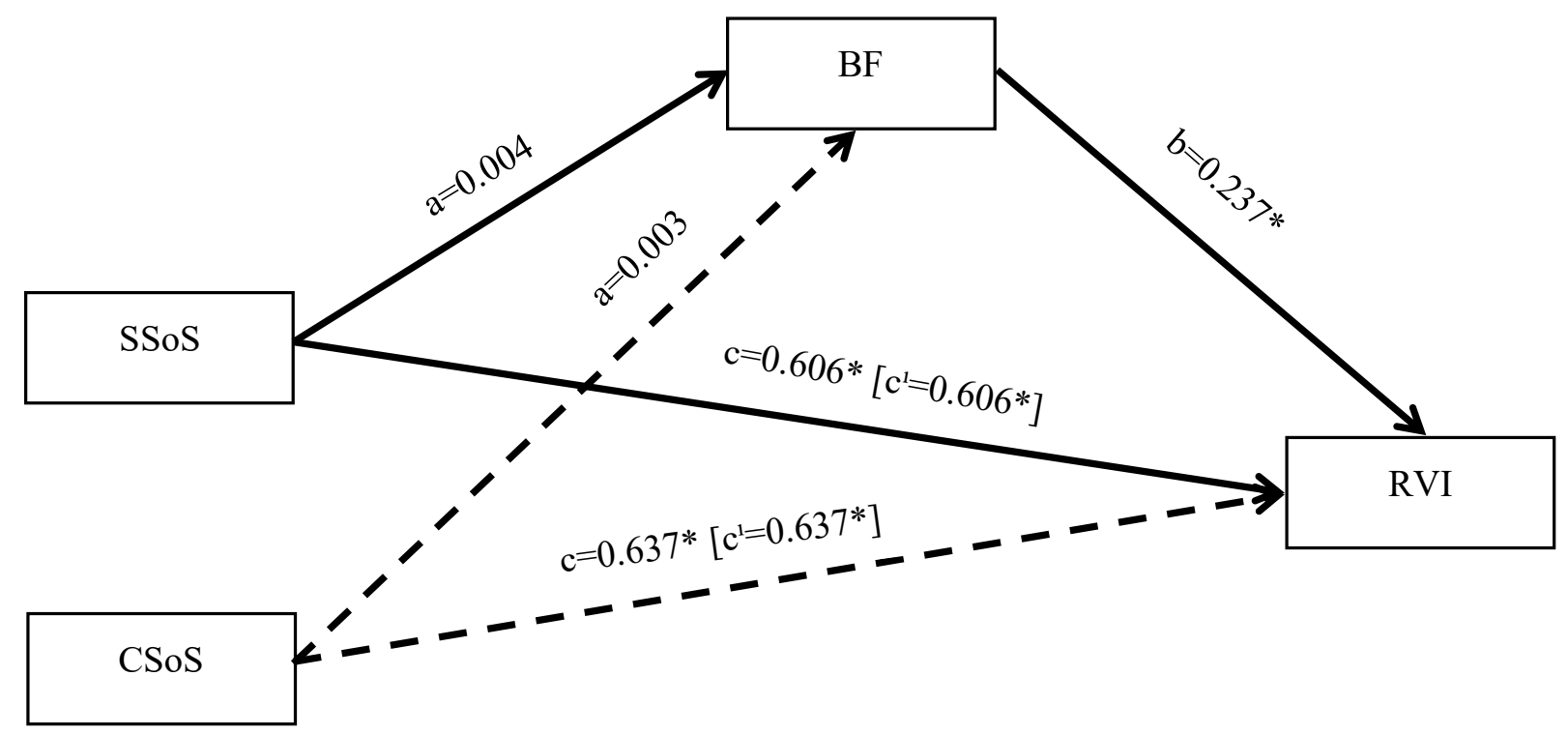

Figure 1. Simple Mediation Using PROCESS macro (Model 4)

familiarity. Also, consistent with previous research in the restaurant industry (Dedeoglu et al., 2018; Lin \& Mattila, 2010), CSoS was more influential on perceptions of RVI than SSoS. However, it was determined that SSoS was more effective in the brand familiarity mediation effect (Park et al., 2019). As familiarity increases, so can customer expertise, which can significantly affect customers' responses (Mitchell \& Dacin, 1996; Park et al., 2019; Tam, 2008). However, the direct effect of servicescape dimensions on brand familiarity could not be determined. Brand familiarity may not directly affect the aesthetic and visual elements in the servicescape affect the pleasurable and emotional value (Dedeoglu et al., 2018). These findings are new to restaurant industry research. As stated by Park et al. (2019) and Dedeoglu et al. (2018), brand familiarity and previous experiences have a role in the servicescape context. Still, the servicescape outputs may be related to creating hedonic elements in its direct impact on brand familiarity. Interaction between employees and customers, $\mathrm{CSoS}$ is an important component (Dedeoglu et al., 2015). On the other hand, SSoS is associated with physical evidence, but, according to Gestalt theory, customers' perception of the environment as a whole reveals the CSoS role. Accordingly, as employees play an important role in consumers' emotional reactions (Dedeoglu et al., 2018), social interactions between customers and restaurant staff play an important role in customers' revisit intention. Moreover, while brand familiarity has been extensively researched in the marketting literature (Kent \& Allen, 1994; Machleit \& Wilson, 1988), there are very few studies, particularly in the restaurant sector. This study determined that brand familiarity has an intermediary role and contributes to this field.

\subsection{Practical Implications}

The results of this study have some interesting practical implications for restaurants. Although most restaurants are aware of the importance of a basic servicescape for their guests. This study shows that they should pay close attention to communicative servicescape. Both of these servicescape factors have been shown to influence revisit intentions. At

Table 2. Structural Path Estimates.

\begin{tabular}{lllcccccc}
\hline Input (X) & Mediator & \multicolumn{1}{c}{ Model } & $\boldsymbol{\beta}$ & SE & $\mathbf{t}$ & $\mathbf{p}$ & LLCI & ULCI \\
\hline \multirow{6}{*}{ SSoS } & \multirow{3}{*}{ BF } & SSoS --> BF (path a) & 0.0004 & 0.0204 & & & -0.0396 & 0.0404 \\
& & BF --> RVI (path b) & 0.2367 & 0.0575 & 4.1144 & 0.0000 & 0.1237 & 0.3496 \\
& & SSoS --> RVI (path c) & 0.6062 & 0.0303 & 19.9822 & 0.0000 & 0.5466 & 0.6658 \\
& & SSoS --> RVI (path c1) & 0.6063 & 0.0307 & 19.7522 & 0.0000 & 0.5460 & 0.6666 \\
& & Indirect Effects of BF & 0.0200 & 0.0048 & & & -0.0096 & 0.0099 \\
\hline \multirow{4}{*}{ CSoS } & \multirow{3}{*}{ BF } & CSoS --> BF (path a) & 0.0033 & 0.0207 & & & -0.0374 & 0.0440 \\
& & CSoS --> RVI (path c) & 0.6365 & 0.0303 & 21.0280 & 0.0000 & 0.5771 & 0.6959 \\
& & CSoS --> RVI (path ci) & 0.6373 & 0.0306 & 20.8113 & 0.0000 & 0.5771 & 0.6974 \\
& & Indirect Effects of BF & 0.0180 & 0.0049 & & & -0.0089 & 0.0108 \\
\hline
\end{tabular}

${ }^{*}$ Note: SSoS: Substantive Staging of Servicescape, CSoS: Communicative Staging of Servicescape, BF: Brand Familiar, RVI: Revisit Intention, LLCI: Lower Level Confidence Interval, ULCI: Upper-Level Confidence Interval. cl: Total Effect 
the same time, a mediating role for brand familiarity has been identified.

This shows that the communicative environment prepared for the chain restaurant business will contribute more to customer satisfaction. In this context, more attention should be paid to the aesthetic competencies of the employees. No matter how well-known the brand is or how striking its architecture is, if these businesses do not pay enough attention to their servicescape's communicative aspects, they may face customer dissatisfaction. With iconic brands and striking architecture, it can surprise guests during their first visit. When the business uses its servicescape effectively, customers play a role in their revisit intention when they become familiar with the brand.

\subsection{Limitations and Future Research}

There are a few limitations to consider for future research. First, this study was carried out with local participants in Istanbul. Therefore, intercultural differences have not been investigated. Future research may investigate cultural differences. This research is also examined in the context of a chain of restaurants. Researchers can include different restaurants in their study. In the restaurants in different destinations in Turkey comparable results by this research. Servicescape may differ according to restaurant concepts. For example, a comparison can be made with this study by conducting this research on themed restaurants. The study results can be expanded by including the phobias caused by Covid-19, for example, with different mediator effects.

\section{References}

Bagozzi, R. P. (1975). Marketing as Exchange. J. Mark., 39(4), 32-39.

Baker, J. (1987). The Role of Environment in Marketing Services: The Consumer Perspective. In Cepeil, J., Congram, C. and Shanahan, J. (Eds), The Services Challenge: Integrating for Competitive Advantage, American Marketing Association, Chicago, IL, pp. 79-84.

Bitner, M.J., 1992. Servicescape: The Impact of Physical Surroundings on Customers and Employees. J. Mark., 56(2), 57-71.

Booms, B. H. \& Bitner, M. J. (1981). Marketing Strategies and Organizational Structures for Service Firms. In Donnelly, J. H. and George, W. R. (Eds), Marketing of Services, American Marketing Association, Chicago, IL, pp. 47-51.

Chang, K. C. (2016). Effect of Servicescape on Customer Behavioral Intentions: Moderating Roles of Service Climate and Employee Engagement. International Journal of Hospitality Management, 53, 116-128.

Cokluk, O., Sekercioglu, G. \& Buyukozturk, S. (2012). Sosyal Bilimler için Çok Değişkenli istatistik SPSS ve LISREL Uygulamaları [Multivariate Statistics for Social Sciences: SPSS and LISREL Applications]. Ankara: Pegem Akademi.

Dedeoglu, B. B., Bilgihan, A., Ye, B. H., Buonincontri, P. \& Okumus, F. (2018). The Impact of Servicescape on Hedonic Value and Behavioral Intentions: The
Importance of Previous Experience. International Journal of Hospitality Management, 72, 10-20.

Dedeoglu, B. B., Kucukergin, K. G. \& Balikcioglu, S. (2015). Understanding the Relationships of Servicescape, Value, Image, Pleasure, and Behavioral Intentions Among Hotel Customers. Journal of Travel and Tourism Marketing, 32(1), S42-S61.

Dong, P. \& Siu, N. Y. M. (2013). Servicescape Elements, Customer Predispositions and Service Experience: The Case of Theme Park Visitors. Tourism Management, 36 (June), 541-551.

Durna, U. Dedeoglu, B. B. \& Balikcioglu, S. (2015). The Role of Servicescape and Image Perceptions of Customers on Behavioral Intentions in the Hotel Industry. International Journal of Contemporary Hospitality Management, 27 (7), 1728-1748.

Ellen, T. \& Zhang, R. (2014). Measuring the Effect of Company Restaurant Servicescape on Patrons' Emotional States and Behavioral Intentions. Journal of Foodservice Business Research, 17 (2), 85-102.

Fornell, C. \& Larcker, D. F. (1981). Structural Equation Models with Unobservable Variables and Measurement Error: Algebra and Statistics. Journal of Marketing Research, 18 (3), 382-388.

Genc, V. \& Akoglan Kozak, M. (2020). Emotional and Social Competence in the Aestheticization of Labor in the Restaurant Industry. International Journal of Contemporary Hospitality Management, 32 (3), 12011225.

Genç, V. (2018). Duygusal ve Sosyal Yetkinliklerin Estetik Emek Üzerine Etkisi: Bir Restoran Zinciri Örneği [The Effect of Emotional and Social Competencies on Aesthetic Labor: An Example of a Restaurant Chain] (Unpublished Doctorate Dissertation). Eskisehir: Anadolu Üniversity Graduate School of Social Sciences.

Gwinner, K., Gremler, D. \& Bitner, M. J. (1998). Relational Benefits in Services Industries: the Customer's Perspective. Journal of the Academy of Marketing Science, 26 (2), 101-114.

Han, H. \& Ryu, K. (2009). The Roles of the Physical Environment, Price Perception, and Customer Satisfaction in Determining Customer Loyalty in the Restaurant Industry. Journal of Hospitality \& Tourism Research, 33, 487-510.

Hanks, L. \& Line, N. D. (2018). The Restaurant Social Servicescape: Establishing a Nomological Framework. International Journal of Hospitality Management, 74(July 2017), 13-21. https://doi.org/10.1016/j. ijhm.2018.01.022

Hanks, L., Line, N. \& Kim, W. G. (Woody). (2017). The Impact of the Social Servicescape, Density, and Restaurant Type on Perceptions of Interpersonal Service Quality. International Journal of Hospitality Management, 61, 35-44.

Harris, L. C. \& Ezeh, C. (2008). Servicescape and Loyalty Intentions: An Empirical Investigation. European Journal of Marketing, 42 (3-4), 390-422.

Hayes, A. F. (2018). Introduction to Mediation, Moderation, and Conditional Process Analysis: A Regression-Based Approach. New York: Guilford Publications.

Jang, Y., Ro, H. \& Kim, T. H. (2015). Social Servicescape: 
The Impact of Social Factors on Restaurant Image and Behavioral Intentions. International Journal of Hospitality and Tourism Administration, 16 (3), 290-309.

Kent, R. J. \& Allen, C. T. (1994). Competitive Interference Effects in Consumer Memory for Advertising: The Role of Brand Familiarity. J. Mark. 58, 97-105.

Kim, W. G. \& Moon, Y. J. (2009). Customers' Cognitive, Emotional, and Actionable Response to the Servicescape: A Test of the Moderating Effect of the Restaurant Type. International Journal of Hospitality Management, 28 (1), 144-156.

Kotler, P. (1973). Atmospherics as a Marketing Tool. Journal of Retailing, 49 (4), 48-64.

Lin, I. Y. \& Mattila, A. S. (2010). Restaurant Servicescape, Service Encounter, and Perceived Congruency on Customers' Emotions and Satisfaction. Journal of Hospitality Marketing and Management, 19 (8), 819841.

Lin, Y. C. (2013). Evaluation of Co-Branded Hotels in the Taiwanese Market: The Role of Brand Familiarity and Brand Fit. International Journal of Contemporary Hospitality Management, 25 (3), 346-364.

Line, N. D. \& Hanks, L. (2019). The Social Servicescape: A Multidimensional Operationalization. Journal of Hospitality \& Tourism Research, 43 (2), 167-187.

Line, N., Hanks, L. \& Kim, W. G. (2018). An Expanded Servicescape Framework as the Driver of Place Attachment and Word of Mouth. Journal of Hospitality \& Tourism Research, 42, 476-499.

Lockwood, A. \& Pyun, K. (2019). How do Customers Respond to the Hotel Servicescape? International Journal of Hospitality Management, 82 (November 2018), 231241.

Machleit, K. A. \& Wilson, R. D. (1988). Emotional Feelings and Attitude Toward the Advertisement: The Roles of Brand Familiarity and Repetition. J. Advert, 17 (3), 27-35.

Mehrabian, A. \& Russell, (1974). An Approach to Environmental Psychology, Cambridge, MA: MIT Press.

Meng, B. \& Choi, K. (2017). Theme Restaurants' Servicescape in Developing Quality of Life: The Moderating Effect of Perceived Authenticity. International Journal of Hospitality Management, 65, 89-99.

Meng, B. \& Choi, K. (2018). An Investigation on Customer Revisit Intention to Theme Restaurants: The Role of Servicescape and Authentic Perception. International Journal of Contemporary Hospitality Management, 30 (3), 1646-1662.

Meydan, C. H. \& Sesen, H. (2011). Yapısal Eşitlik Modellemesi AMOS Uygulamaları [Structural Equation Modeling AMOS Applications]. Ankara: Detay Yayıncılık.

Mitchell, A. A. \& Dacin, P. A. (1996). The Assessment of Alternative Measures of Consumer Expertise. J. Consum. Res., 23, 219-239.

Park, J. Y., Back, R. M., Bufquin, D. \& Shapoval, V. (2019). Servicescape, Positive Affect, Satisfaction and Behavioral Intentions: The Moderating Role of Familiarity. International Journal of Hospitality Management, 78 (June 2018), 102-111.

Pizam, A. \& Tasci, A. D. A. (2019). Experienscape: Expanding the Concept of Servicescape with a Multi-Stakeholder and Multi-Disciplinary Approach (invited paper for 'luminaries' special issue of International Journal of
Hospitality Management). International Journal of Hospitality Management, 76 (June 2018), 25-37.

Podsakoff, P. \& Organ, D. (1986). Reports in Organizational Research: Problems and Prospects. Journal of Management, 12, 531-544.

Ryu, K. \& Jang, S. S. (2008). The Influence of the Physical Environment on Customer Emotions and Behavioral Intentions: The Application of Modified MehrabianRussell Model. The Service Industries Journal, 28 (8), 1151-1165.

Tabachnick, G. B. \& Fidel, S. L. (2013). Using Multivariate Statistics. Boston: Pearson.

Taheri, B., Olya, H., Ali, F. \& Gannon, M. J. (2020). Understanding the Influence of Airport Servicescape on Traveler Dissatisfaction and Misbehavior. Journal of Travel Research, 59 (6), 1008-1028.

Tam, J. L. M. (2008). Brand Familiarity: Its Effects on Satisfaction Evaluations. J. Serv. Market., 22 (1), 3-12.

Turker, N., Gokkaya S. \& Acar, A. (2019). Measuring the Effect of Restaurant Servicescapes on Customer Loyalty. Tourism Academic Journal, 6 (2), 255-270.

Wang, C. Y. \& Mattila, A. S. (2015). The Impact of Servicescape Cues on Consumer Pre- purchase Authenticity Assessment and Patronage Intentions to Ethnic Restaurants. J. Hosp. Tour. Res., 39 (3), 346-372.

Wertheimer, M. (1938). Gestalt Theory. In W. D. Ellis (Ed.), A Source Book of Gestalt Psychology (pp. 1-11). Kegan Paul, Trench: Trubner \& Company.

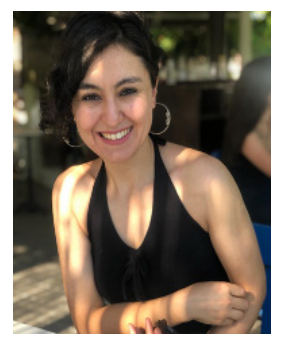

Seray Gulertekin Genc, is a PhD at the School of Tourism and Hotel Management at Batman University. She graduated a PhD in Tourism Management at Eskisehir Eskisehir Osmangazi University in Turkey. She is studying the aesthetic of the destination.

\section{ORCID: 0000-0002-0655-2856}

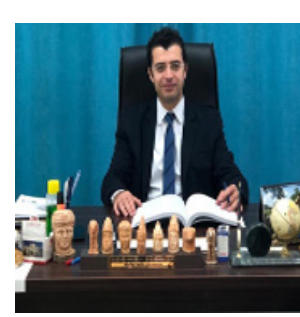

Volkan Genc, is an assistant professor at the School of Tourism and Hotel Management at Batman University. He graduated a PhD in Tourism Management at Eskisehir Anadolu University in Turkey. He continues to work on emotional and social competence, emotional labor, aesthetic labor, and the role of employee's emotions in resistance to change.

ORCID: 0000-0001-5887-0568 